\title{
Vključevanje priseljenskih učencev v slovenski zakonodaji in šolski praksi
}

\author{
Andreja Sinjur \\ OŠ Dušana Bordona Semedela, Koper \\ Univerza na Primorskem, Pedagoška fakulteta
}

\section{Uvod}

Slovenija je članica Organizacije združenih narodov, UNESCA, EU in Sveta Evrope. Po 2. svetovni vojni so bili v okviru teh organizacij izdani mnogi dokumenti, ki obravnavajo področje izobraževanja zlasti $\mathrm{z}$ vidika človekovih pravic, enakih možnosti in kulturne raznolikosti. Ti dokumenti narekujejo smernice medkulturnega izobraževanja in tudi izobraževanja priseljenskih učencev. Podpisnica teh dokumentov je tudi Slovenija. Že Konvencija o otrokovih pravicah (1989) v 30. členu poudarja, da v tistih državah, $\mathrm{v}$ katerih živijo etnične, verske, jezikovne manjšine ali osebe staroselskega porekla, otroku, ki pripada taki manjšini ali ki je staroselec, ne sme biti vzeta pravica, da skupaj z drugimi člani svoje skupine uživa svojo lastno kulturo, izpoveduje in izraža svojo lastno vero in da uporablja svoj lastni jezik. V Sloveniji zagotavljanje pravic priseljenskih učencev urejajo različni zakoni in dokumenti, ki jih predstavljamo v nadaljevanju.

\section{Slovenski zakonodajni in strokovni dokumenti}

\section{Dokumenti, ki se nanašajo na pravico do vključevanja v osnovno šolo, in načelo enakih možnosti}

Pravice do vključevanja priseljenskih učencev v slovensko osnovno šolo urejajo Zakon o organizaciji in financiranju vzgoje in izobraževanja, Zakon o osnovni šoli ter Pravilnik o preverjanju in ocenjevanju znanja ter napre- 
dovanju učencev v osnovni šoli. Zakon o osnovni šoli (2007) v 10. členu otrokom, ki so tuji državljani, zagotavlja pravico do obveznega osnovnošolskega izobraževanja pod enakimi pogoji kot državljanom Republike Slovenije. Zakon o organizaciji in financiranju vzgoje in izobraževanja (2007) v 2. členu izpostavlja cilje sistema vzgoje in izobraževanja:

- zagotavljanje optimalnega razvoja posameznika ne glede na spol, socialno in kulturno poreklo, veroizpoved, rasno, etnično in narodno pripadnost, telesno in duševno zgradbo ali invalidnost;

- $\quad$ zagotavljanje enakih možnosti za vzgojo in izobraževanje otrok iz socialno manj spodbudnih okolij.

Tudi Bela knjiga (2011, str. 16-17) med splošnimi cilji vzgoje in izobraževanja poudari zagotavljanje enakih možnosti za vzgojo in izobraževanje vsakega posameznika (ne glede na spol, socialno in kulturno poreklo, veroizpoved, narodno pripadnost, svetovnonazorsko pripadnost in telesno ter duševno konstitucijo) ter nudenje ustrezne pomoči in spodbud posameznikom oz. skupinam (tj. priseljencem, ki prihajajo iz socialno in kulturno manj spodbudnega okolja, in osebam s posebnimi potrebami, ki imajo odločbo o usmeritvi).

Med načeli in cilji nadaljnjega razvoja osnovne šole Bela knjiga (2011, str. 48) poudari načelo enakih možnosti in optimalnega razvoja posameznika, in sicer zaradi individualnih razlik med učenci predlaga pestro ponudbo dejavnosti in uporabo različnih učnih pristopov $\mathrm{z}$ namenom zmanjševanja razlik med učenci, ki so povezane $\mathrm{z}$ njihovim socialno-kulturnim in jezikovnim okoljem. Torej predlaga možnost pozitivne diskriminacije za povečanje enakih izobraževalnih možnosti za otroke iz socialno in kulturno depriviligiranih okolij.

\section{Dokumenti, ki vključujejo načelo medkulturnosti}

$\mathrm{V}$ zakonodajnih dokumentih terminov, kot so večkulturnost, medkulturnost, spodbujanje medkulturnih odnosov in podobno, ne najdemo, vendar pa nekateri cilji predstavljajo izhodišče za razvoj medkulturne vzgoje in izobraževanja (Vižintin, 2013). Izhodišča za razvoj medkulturnega izobraževanja omogoča že Zakon o organizaciji in financiranju vzgoje in izobraževanja (1996) z dopolnitvami, ki v 2. členu navaja cilje sistema vzgoje in izobraževanja, med katerimi so naslednji povezani z medkulturnim izobraževanjem: 
- zagotavljanje optimalnega razvoja posameznika ne glede na spol, socialno in kulturno poreklo, veroizpoved, rasno, etnično in narodno pripadnost, telesno in duševno zgradbo ali invalidnost;

- vzgajanje za medsebojno strpnost, razvijanje zavesti o enakopravnosti spolov, spoštovanje drugačnosti in sodelovanje $z$ drugimi, spoštovanje otrokovih in človekovih pravic in temeljnih svoboščin, razvijanje enakih možnosti obeh spolov ter s tem razvijanje sposobnosti za življenje v demokratični družbi;

- razvijanje zavesti o državni pripadnosti in nacionalni identiteti in vedenja o zgodovini Slovenije in njeni kulturi;

- $\quad$ vzgajanje in izobraževanje za trajnostni razvoj in dejavno vključevanje $\mathrm{v}$ demokratično družbo, kar vključuje globlje poznavanje in odgovoren odnos do sebe, svojega zdravja, drugih ljudi, svoje in drugih kultur, naravnega in družbenega okolja, prihodnjih generacij;

- na območjih, ki so opredeljena kot narodno mešana, je omogočeno ob razvijanju slovenskega jezika tudi ohranjanje in razvijanje italijanskega in madžarskega jezika.

V 2. členu Zakona o osnovni šoli (1996) so navedeni naslednji cilji:

- $\quad$ vzgajanje za obče kulturne in civilizacijske vrednote, ki izvirajo iz evropske tradicije;

- $\quad$ vzgajanje za medsebojno strpnost, spoštovanje drugačnosti in sodelovanje $\mathrm{z}$ drugimi ter spoštovanje človekovih pravic in temeljnih svoboščin in s tem razvijanje sposobnosti za življenje v demokratični družbi;

- $\quad$ seznanjanje $\mathrm{z}$ drugimi kulturami in učenje tujih jezikov.

Ministrstvo za šolstvo in šport (danes Ministrstvo za izobraževanje, znanost in šport) je maja 2007 sprejelo Strategijo vključevanja otrok, učencev in dijakov migrantov $v$ sistem vzgoje in izobraževanja $v$ Republiki Sloveniji. V dokumentu je podana analiza stanja, našteti so problemi pri vključevanju priseljenskih učencev v slovenski vzgojno-izobraževalni sistem ter navedene zakonske podlage, ki obravnavajo njihovo izobraževanje. $\mathrm{V}$ dokumentu so poudarjena načela vključevanja in predlagani ukrepi, ki bi pripomogli k izboljšanju razmer na omenjenem področju. S predlaganimi ukrepi avtorji pokažejo na potrebo po oblikovanju ustreznih zakonskih aktov, ki naj jih pripravijo pristojna ministrstva s pomočjo institucij, kot sta Center za slovenščino kot drugi/tuji jezik in Zavod Republike Slovenije za 
šolstvo. V Strategiji (2007, str. 12) so opredeljeni tudi cilji vključevanja priseljenskih učencev:

- na sistemski ravni zagotavljanje pogojev, možnosti in priložnosti, ki omogočajo doseganje ciljev oz. standardov znanja, ki so opredeljeni v učnih načrtih;

- $\quad$ uspešna vključenost otrok migrantov v šolsko, socialno in pozneje poklicno okolje;

- razvijanje zmožnosti za predstavljanje lastne kulture, zaznavanje, razumevanje in sprejemanje drugačnosti za premagovanje predsodkov do drugih kultur, primerjanje kultur, vzgajanje k strpnosti, ohranjanje oz. nadgrajevanje lastne identitete in kulture;

- $\quad$ znanje slovenščine v taki meri, da zagotavlja uspešno vključevanje v sistem vzgoje in izobraževanja, to pa pomeni:

- razvijanje jezikovne zmožnosti (otroci usvojijo oz. se naučijo zadostnega nabora besedišča, slovničnih in sporazumevalnih vzorcev za uspešno sporazumevanje v šolskem okolju: sporazumevanje z učitelji, sporazumevanje z vrstniki, dejavno sodelovanje pri pouku);

- razvijanje socialne zmožnosti (zmožnost izražanja mnenja, želja, namere oz. ustreznega reagiranja na želje drugih. Otroci imajo to zmožnost že razvito, vendar so jo razvili v lastnem okolju in jo znajo realizirati le v svojem jeziku ter na način, ki ustreza ustaljenim vzorcem v njihovem sociokulturnem okolju. Učenje jezika je tudi socializacijski proces, prilagajanje novim življenjskim okoliščinam, govornim položajem);

- razvijanje spoznavne zmožnosti (širjenje otrokovega pojmovnega sveta).

M. Vižintin (2013, str. 191) ugotavlja, da je Strategija (2007) v slovenski prostor prinesla kritičen, realen in do leta 2007 najbolj natančen pogled na pomanjkljivo slovensko zakonodajo in neurejene razmere pri vključevanju otrok priseljencev ter tudi predloge za spremembe.

Zavod Republike Slovenije za šolstvo je na podlagi Strategije leta 2009 izdal dokument Smernice za izobraževanje otrok tujcev v vrtcih in šolah (2009), leta 2012 pa je omenjeni dokument dopolnil in izboljšal ter izdal Smernice za vključevanje otrok priseljencev v vrtce in šole (2012). Smernice (2012) opredeljujejo ukrepe, strategije, prilagoditve za delo in načine sodelovanja ter vključevanja otrok in njihovih staršev na področju vzgoje 
in izobraževanja. S konkretnimi predlogi za uspešno vključevanje priseljenskih učencev podpirajo razvoj medkulturne vzgoje in izobraževanja. Namenjene so tako za delo s priseljenskimi učenci kot tudi za vso populacijo učencev. Upoštevano je načelo avtonomije, zato vsaka vzgojno-izobraževalna ustanova sama pripravi izvedbeni načrt aktivnosti, ki vključuje in upošteva značilnosti in posebnosti učenca ter $\mathrm{v}$ skladu $\mathrm{z}$ veljavnimi predpisi in pričujočimi smernicami poišče najustreznejše rešitve konkretnih problemov.

Bela knjiga (2011, str. 45) slovenske družbe sicer še ne opredeljuje kot večkulturne, vendar pa poudarja vzgojo za medkulturnost, kar razberemo iz naslednjega: »Z veliko verjetnostjo je mogoče predvidevati, da bo Slovenija postajala večkulturna država, ki bo zaznamovana $\mathrm{z}$ intenzivnejšimi medkulturnimi vplivi, zato je treba že danes misliti na prihodnje razmere in pripravljati sedanje generacije na življenje v spremenjenih razmerah. Predvidevamo lahko, da bo naša družba vse bolj odprta tudi za priseljevanje ljudi iz drugih kulturnih okolij, zato je pomembno vzgajati in izobraževati za medsebojno spoštovanje in dialog.« Hkrati Bela knjiga (2011, str. 116-117) opredeli šolo kot prostor, v katerem se srečujejo posamezniki različnih narodnosti, socialno-kulturnih okolij, etičnih skupin, veroizpovedi, svetovnonazorskih prepričanj in podobno. Berdajs (2016) pravi, da je treba vzgojno-izobraževalno delo organizirati tako, da bo spoštovalo človekove pravice in temeljne svoboščine ter omogočalo optimalen razvoj vsem otrokom ne glede na izobrazbo njihovih staršev, njihov socialno-ekonomski položaj, narodno pripadnost, spol in podobno. Bela knjiga (2011, str. 116-117) pravi, da se mora šola pri vzgoji osredotočiti zlasti na razvijanje medsebojne strpnosti, solidarnosti, odgovornosti, spoštovanja drugačnosti, medgeneracijskega sožitja in s tem na razvijanje sposobnosti za življenje $\mathrm{v}$ demokratični družbi. Med načeli izpostavi načelo oblikovanja in širjenja nacionalne kulture in spodbujanja medkulturnosti, ki vključuje poznavanje in oblikovanje kulture, oblikovanje zavesti o pomenu kulture in spodbujanje medkulturnosti. Poleg razvijanja in ohranjanja lastne kulturne tradicije šola spodbuja medkulturnost, seznanja učence $\mathrm{z}$ obče kulturnimi in $\mathrm{s}$ civilizacijskimi vrednotami, $\mathrm{z}$ drugimi kulturami in prispeva $\mathrm{k}$ spoštovanju pluralizma kultur. Posebno pozornost je treba nameniti tudi kulturam učencev priseljencev. Med cilji osnovne šole pa Bela knjiga (2011, str. 118) navede, da razvija sposobnosti za razumevanje različnosti:

spoštovanje človekovih pravic in temeljnih svoboščin ter vzgajanje za udejanjanje dolžnosti posameznika, ki izhajajo iz teh pravic; 
- $\quad$ vzgajanje za medsebojno strpnost, spoštovanje drugačnosti in sodelovanje $z$ drugimi;

- poznavanje, razvijanje in ohranjanje lastne kulture, razvijanje narodne identitete in spoznavanje kultur drugih narodov;

- $\quad$ vzgajanje za obče kulturne in civilizacijske vrednote, ki izvirajo iz evropske tradicije.

\section{Dokumenti, ki obravnavajo učenje slovenščine kot jezika okolja}

Vloga slovenščine kot enega od ključnih pogojev za uspešno vključevanje priseljenskih učencev v slovenske šole je bila $\mathrm{v}$ šolskih dokumentih prvič jasneje izpostavljena v Strategiji (2007). V tem dokumentu je tudi jasno izraženo, da gre pri priseljenskih učencih večinoma za govorce slovenščine kot drugega jezika, ki potrebujejo drugačen način poučevanja slovenščine. Zakon o osnovni šoli (8. člen) že od leta 1996 predvideva možnost, da se za otroke slovenskih državljanov, ki prebivajo v Republiki Sloveniji in katerih materni jezik ni slovenski jezik, lahko dodatno organizira pouk slovenskega jezika. Torej za priseljenske učence prve generacije, ki so se vključili v osnovno šolo, ni bil predviden dodatni pouk slovenščine. To je bilo omogočeno šele novembra 2007, ko imajo priseljenski otroci, pri katerih materni jezik ni slovenščina in nimajo državljanstva RS, po priselitvi v Slovenijo pravico do tečaja slovenščine (Zakon o osnovni šoli, 2007, 10. člen).

Tudi Smernice (2012) izpostavljajo učenje slovenščine kot ključni element za zagotavljanje možnosti komunikacije. Šola naj spodbuja učenje jezika učnega okolja, to je slovenščine, in maternega jezika posameznega otroka. Za priseljenske otroke s pomanjkljivim znanjem slovenščine mora šola ob vstopu v skladu z možnostmi organizirati učenje in izpopolnjevanje slovenščine, pri čemer se stopnja in obseg učenja prilagodita ravni ugotovljenih individualnih jezikovnih zmožnosti in potrebam. Po potrebi se tudi v nadaljnjih letih šolanja organizira pomoč pri učenju slovenščine v okviru nadaljevalnih tečajev, dopolnilnega pouka, obveznih izbirnih predmetov. Smernice (2012) opozarjajo, da mora šola zagotoviti, da priseljenske učence poučujejo učitelji, ki so usposobljeni za poučevanje slovenščine kot drugega jezika in imajo razvite medkulturne kompetence. Zagotavljanje učenja slovenščine kot drugega jezika je izpostavljeno tudi v Resoluciji o nacionalnem programu za jezikovno politiko 2014-2018 (2013). Med ukrepi so navedeni: prenova normativov in standardov $\mathrm{z}$ vidika uvedbe uvajalnih intenzivnih tečajev slovenščine za priseljenske učence; oblikovanje učnega načrta za slovenščino kot drugi jezik v osnovni šoli na podlagi definiranega obsega 
in oblike učenja slovenščine kot drugega/tujega jezika; izdelava ustreznih e-gradiv (vključno s priročniki, kot so slovnica in slovarji), namenjenih za samostojno učenje in kombinirano učenje za najrazličnejše ciljne publike.

\section{Zakonske podlage, ki urejajo področje učenja maternega jezika priseljenskih učencev}

Evropski parlament (2009) poziva vlade držav članic, naj otrokom zakonitih priseljencev zagotovijo brezplačno izobraževanje, hkrati z učenjem uradnega jezika države gostiteljice in maternih jezikov priseljenskih učencev. Slovenija mora kot članica EU na podlagi načela enakih pravic učencem ponuditi učenje maternega jezika. V državah članicah EU obstajata dva glavna pristopa $\mathrm{k}$ učenju maternega jezika priseljenskih učencev: Direktiva Sveta Evropske skupnosti o izobraževanju otrok delavcev migrantov iz leta 1977 in dvostranski sporazumi s tretjimi državami, ki niso članice EU (Sinjur, 2010). Ohranjanje maternega jezika priseljenskih učencev je tudi ustavna pravica, saj Ustava Republike Slovenije v 61. členu določa, da ima vsakdo pravico, da svobodno izraža pripadnost svojemu narodu ali narodni skupnosti, da goji in izraža svojo kulturo in uporablja svoj jezik in pisavo (Ustava, 2006). Zakonodaja že od leta 1996 omogoča možnost učenja maternega jezika, saj predvideva, da se za otroke slovenskih državljanov, ki prebivajo v Republiki Sloveniji in katerih materni jezik ni slovenski jezik, $\mathrm{v}$ skladu $\mathrm{z}$ mednarodnimi pogodbami organizira pouk njihovega maternega jezika in kulture (Zakon o osnovni šoli, 8. člen). Prav tako se v skladu $\mathrm{z}$ mednarodnimi pogodbami organizira pouk maternega jezika in kulture za otroke, ki so tuji državljani oz. osebe brez državljanstva in prebivajo v Republiki Sloveniji (Zakon o osnovni šoli, 10. člen). Zakon o organizaciji in financiranju vzgoje in izobraževanja v 81. členu določa, da država zagotavlja sredstva za poučevanje maternega jezika za tujce, vključene v redno osnovnošolsko izobraževanje. Leta 2011 Zakon o osnovni šoli v 8. členu odpravlja razlikovanje med otroki priseljenci $z$ državljanstvom ali brez njega in predvideva pouk njihovega maternega jezika in kulture s sodelovanjem $\mathrm{z}$ državami izvora. Tudi Bela knjiga (2011) poudarja, da morajo imeti materni jeziki učencev, katerih materinščina ni slovenščina, posebno mesto. Predlaga, da bi imeli priseljenci v osnovni šoli možnost učenja svojega prvega jezika/ materinščine in kulture, saj je dobro razvita jezikovna zmožnost v prvem jeziku eden od temeljnih pogojev za razvoj jezikovne zmožnosti v vseh drugih jezikih. Zato naj šola (lahko tudi v sodelovanju z drugimi šolami) oblikuje skupine za učenje maternega jezika in kulture za učence, katerih ma- 
terni jezik ni slovenščina, v obsegu ene ure na teden za skupino učencev. Prav tako je izhodišče jezikovne politike v Sloveniji, da imajo vsi govorci, katerih prvi jezik ni slovenščina, v skladu s človekovimi pravicami in načeli EU pravico ohranjati in obnavljati lastni jezik in kulturo (Resolucija o nacionalnem programu za jezikovno politiko 2014-2018, 2013).

\section{Zakonodaja o preverjanju in ocenjevanju znanja ter napredovanju priseljenskih učencev}

Pravilnik o preverjanju in ocenjevanju znanja ter napredovanju učencev $v$ osnovni šoli (2013, 15. člen) omogoča od leta 2008 prilagajanje ocenjevanja med šolskim letom: "Za učenca priseljenca iz druge države se lahko v dogovoru s starši med šolskim letom prilagodijo načini in roki za ocenjevanje znanja, število ocen ter drugo. Znanje učenca priseljenca iz druge države se lahko ocenjuje glede na njegov napredek pri doseganju ciljev oz. standardov znanja, opredeljenih v učnih načrtih. O prilagoditvah ocenjevanja med šolskim letom iz tega člena odloči učiteljski zbor. Prilagoditve ocenjevanja med šolskim letom se učencu priseljencu iz druge države upoštevajo največ dve šolski leti po vključitvi v osnovno šolo v Republiki Sloveniji.« Glede nacionalnega preverjanja znanja pa zakonodaja omogoča, da »učenci priseljenci iz drugih držav, katerih materni jezik ni slovenski in se prvič vključijo v osnovno šolo v Republiki Sloveniji v 6. in 9. razredu, opravljajo v tem šolskem letu nacionalno preverjanje znanja prostovoljno« (Zakon o osnovni šoli, 64. člen).

O napredovanju pa v Zakonu o osnovni šoli v 69. členu piše, da so lahko učenci priseljencev iz drugih držav ob koncu pouka v šolskem letu, v katerem so prvič vključeni v osnovno šolo v Republiki Sloveniji, neocenjeni iz posameznih predmetov in napredujejo v naslednji razred. O napredovanju odloči na predlog razrednika učiteljski zbor.

\section{Podporne oblike pomoči priseljenskim učencem v zakonodaji}

\section{Učenje slovenščine kot drugega jezika}

Za priseljenske učence je slovenščina drugi jezik oz. jezik novega okolja, ki se ga morajo naučiti, če se želijo vključiti v to okolje. Hkrati je zanje tudi učni jezik, saj poučevanje poteka v slovenščini. Prav tako pa je glede na predmetnik devetletne osnovne šole slovenščina zanje tudi učni predmet. Z vključitvijo v osnovno šolo so priseljenski učenci postavljeni pred dve nalogi hkrati: učenje nove snovi v jeziku, ki ga ne obvladajo, in (posredno) 
učenje jezika. To ni enako kot učenje jezika. Učenje jezika je osredinjeno na pridobivanje jezikovnih sposobnosti in naj bi potekalo pred vstopom $\mathrm{v}$ šolo, kadar je to možno. Učenje (razumevanje in pomnjenje) nove snovi in seznanjanje z novim jezikom sta za učenca priseljenca zelo težavni nalogi (Knaflič, 2010).

Krek in Vogrinc (2005) ugotavljata, da je pogoj uspešne vključitve učencev iz jezikovno, kulturno in socialno deprivilegiranih družin $\mathrm{v}$ vzgojno-izobraževalni sistem ustrezno začetno opismenjevanje teh učencev. Slabše obvladovanje ali neobvladovanje slovenskega sporazumevalnega jezika vodi do neučinkovitega dela $\mathrm{v}$ šoli, saj učenec ni zmožen slediti pouku zaradi jezikovne pregrade. Problem priseljenski učencev je nezadostno obvladanje slovenskega jezika ob vključevanju v šolski sistem oz. obremenjenost $\mathrm{z}$ vzporednim usvajanjem slovenščine in obvladovanjem učne snovi (Krek in Vogrinc, 2005). Obvladanje učnega jezika je za potek šolanja nujno, saj učenci, ki ne obvladajo učnega jezika, v učnem procesu ne morejo razviti vseh svojih sposobnosti (Knaflič, 2010). Knez (2012) poudari razliko med vsebinami in pristopi pri poučevanju in preverjanju znanja pri prvem ali drugem jeziku. Učenci rojeni govorci svoje dobro znanje slovenščine v šoli nadgrajujejo, učenci priseljenci pa se (običajno) s slovenščino srečujejo prvič in se jo morajo naučiti »od začetka«. Zato je pri načrtovanju začetnega pouka slovenščine za učence priseljence smiselno $\mathrm{v}$ ospredje postaviti tiste vsebine, ki so potrebne za sporazumevanje v vsakdanji komunikaciji in pri spremljanju drugih predmetov, pozneje pa dodati metajezikovna in literarna znanja.

Od leta 2007 Zakon o osnovni šoli (10. člen) predvideva organizacijo tečaja slovenščine za otroke, ki prebivajo v Sloveniji, a so tuji državljani ali osebe brez državljanstva in potrebujejo pomoč pri učenju slovenščine. Šole zaprosijo za finančno pomoč Ministrstvo za izobraževanje, znanost in šport (81. člen Zakona o organizaciji in financiranju vzgoje in izobraževanja), ki jim praviloma financira do 35 ur dodatnega pouka slovenščine na leto za posameznega otroka. V zakonodaji ni določeno, kako bo potekalo učenje slovenščine, ampak je izvedba prepuščena šolam. Poteka zelo različno: kot dodatne ure med/pred poukom ali po njem, v oddelkih podaljšanega bivanja, kot individualna strokovna pomoč, interesna dejavnost ali tečaj (Knez, 2009). Tudi profil učitelja, ki poučuje slovenščino kot drugi jezik, ni določen, torej učitelji, ki poučujejo slovenščino kot drugi jezik, največkrat niso usposobljeni za poučevanje jezika oseb, ki jim slovenščina ni materni jezik. To pomeni, da so priseljenski učenci po 35-urnem te- 
čaju večinoma deležni poučevanja slovenskega jezika kot učenci, ki jim je slovenščina materinščina. Prav tako ustrezne podpore pri svojem pedagoškem delu niso deležni slovenski učitelji, saj so večinoma tako rekoč postavljeni pred dejstvo, da je v razredu učenec, ki slovenskega jezika ne razume (Lesar, Čančar in Jug Došler, 2012). Vižintin (2014, str. 78) poudarja, da je pouk slovenščine kot drugega jezika temeljna oblika podpore za uspešno vključevanje otrok priseljencev v novo okolje, zato je pomembno, da je organiziran strokovno, sistematično in prilagojeno individualnim potrebam. Vendar za poučevanje slovenščine kot drugega jezika ni ustreznega učnega načrta. Upoštevajoč dejstvo, da je slovenščina za nekatere učence materni, za druge pa drugi jezik, K. Skubic Ermenc (2010a) predlaga pripravo učnega načrta za slovenščino kot drugega jezika (kot pri učnih načrtih za madžarsko in italijansko manjšino), s čimer se strinja tudi Bela knjiga (2011). Takšen učni načrt bi bil lahko bodisi osnova za dopolnilni pouk slovenščine bodisi za oblikovanje novega učnega predmeta - slovenščina kot drugi jezik. Vendar pa omenjena avtorica pri tem opozarja, da oblikovanje novega predmeta prinaša tveganje, saj lahko pripomore $\mathrm{k}$ ločevanju učencev. Za čim bolj kakovosten pouk slovenščine kot drugega jezika M. Vižintin (2014) svetuje usposabljanje za poučevanje slovenščine kot drugega jezika, študij strokovne literature s tega področja ter izmenjavo izkušenj z drugimi učitelji slovenščine kot drugega jezika. Predlaga fleksibilno obliko izvajanja pouka slovenščine kot drugega jezika: poleg uvajalnice naj se pouk slovenščine kot drugega jezika izvaja med poukom, na začetku intenzivneje, postopoma pa naj bo otrok vedno več vključen v redni vzgojno-izobraževalni proces.

Tudi Bela knjiga (2011) ugotavlja sistemsko neurejenost. Šole se morajo tako znajti po svoje in izkušnje kažejo, da je njihovo uresničevanje odvisno zlasti od ozaveščenosti in angažiranosti posameznih učiteljev in ravnateljev. Zato Bela knjiga poudari, da je treba nujno ponuditi ustrezno sistemsko rešitev in $\mathrm{v}$ njej natančno opredeliti: obseg dodatnega pouka, njegove obliko in vsebine ter kdo so lahko izvajalci dodatnega pouka in kakšna naj bo njihova strokovna usposobljenost. Predlaga tako obliko učenja slovenščine, ki bo učencem omogočala učinkovito jezikovno napredovanje, hkrati pa jih ne bo izključevala ali marginalizirala. Predlagana je obvezna strnjena začetna oblika jezikovnega tečaja (do 240 ur), ki jo je možno zagotoviti z regijskim medšolskim sodelovanjem. Po potrebi se nadaljuje dodatno učenje slovenščine $\mathrm{v}$ okviru diferenciacije in individualizacije rednega 
pouka, kombinirano s pomočjo učencev s podobno izkušnjo (oblike tutorstva). Posebej je poudarjeno tudi vzpodbujanje staršev $k$ učenju slovenščine.

Stanje se sicer izboljšuje, saj je $\mathrm{v}$ zadnjih letih izšlo nekaj učnega gradiva, ki je učiteljem $\mathrm{v}$ pomoč pri učenju slovenščine kot drugega jezika, Center za slovenščino kot drugi/tuji jezik pa izvaja usposabljanja za učenje slovenščine kot drugega jezika za učitelje.

\section{Učenje maternega jezika}

Formalno-pravno imajo priseljenski učenci (oz. vsi, katerih materni jezik ni slovenščina) v Sloveniji možnost učenja maternega jezika. Vendar pa uresničevanje teh pravic ni sistemsko urejeno. V praksi se izvaja učenje maternih jezikov učencev priseljencev v obliki dopolnilnega pouka ali izbirnega predmeta. Po sklepu ministra o sofinanciranju dopolnilnega pouka maternih jezikov in kultur za otroke priseljencev v šolskem letu 2014/15 dopolnilni pouk maternega jezika izvaja osnovna šola, sredstva za izvajanje pa zagotavljata Ministrstvo za izobraževanje, znanost in šport ter države, katerih jezik se poučuje, ali starši učencev, ki bodo pouk obiskovali, ali druge osebe. Države, katerih jezik se poučuje, ali starši ali druge osebe zagotavljajo plačilo učitelja ter njegove potne stroške, medtem ko Ministrstvo za izobraževanje, znanost in šport zagotavlja letni pavšalni znesek na učenca ali dijaka, ki obiskuje dopolnilni pouk, ki zadostuje za plačilo uporabe prostorov (najmanj) 6o ur pouka, nabavo učil in učnih pripomočkov za učenca ter materialne stroške za izvedbo programa (fotokopiranje, telefon, drobni potrošni material in drugo).

Druga možnost učenja maternega jezika je v obliki izbirnega predmeta, pri katerem pa ti jeziki niso opredeljeni kot prvi jeziki, temveč se obravnavajo kot tuji. Kljub dobro urejeni teoretični podlagi učenja maternega jezika učencev priseljencev pa je v praksi le nekaj šol, ki ponujajo in izvajajo učenje maternega jezika. Priseljenski učenci iz Makedonije se lahko učijo materni jezik od leta 1993, v zadnjih letih pa tudi priseljenci iz drugih držav. Za učence priseljence iz držav EU Slovenija trenutno na podlagi Direktive Sveta Evropske skupnosti (1977) sofinancira pouk nemščine in finščine. Na podlagi bilateralnih sporazumov pa Ministrstvo za izobraževanje, znanost in šport sofinancira dopolnilno učenje albanščine, ruščine in makedonščine. Dopolnilno učenje hrvaščine financira država Hrvaška sama (Sinjur, 2010). V manjšem številu šol pa se izvaja učenje maternih jezikov kot izbirnega jezika (Komac, Medvešek in Roter, 2007). 
Smernice (2012) spodbujajo branje knjig in drugih publikacij v maternem jeziku in organiziranje bralne značke $v$ maternih jezikih. O pomenu maternega jezika bi bilo treba izobraziti tudi pedagoške delavce, saj raziskava (Krek in Vogrinc, 2011) ugotavlja, da le dobra tretjina osnovnošolskih učiteljev ( $38 \%)$ meni, da bi šola morala poskrbeti, da bi se učenci, katerih materni jezik ni slovenščina, učili tudi svoje materne jezike.

\section{Prilagoditve metod in oblik dela}

V skupino učencev $\mathrm{z}$ učnimi težavami so vključeni tudi učenci, katerih težave pri učenju so posledica kulturne in ekonomske prikrajšanosti ter težave, povezane $z$ večjezičnostjo in večkulturnostjo (Magajna idr., 2008), torej $\mathrm{v}$ to skupino sodijo tudi priseljenski učenci.

Zakon o osnovni šoli $\mathrm{v}$ 12. členu navaja, da so osnovne šole učencem $\mathrm{z}$ učnimi težavami dolžne prilagajati metode in oblike dela ter zagotavljati dopolnilni pouk in druge oblike individualne in skupinske pomoči. Država financira izvedbo dopolnilnega pouka (1 uro dopolnilnega in dodatnega pouka na oddelek) in pol ure drugih oblik individualne in skupinske pomoči na oddelek (Zakon o financiranju, 81. člen).

Učenci priseljenci so tako upravičeni do prilagajanja metod in oblik dela med poukom, obiskovanja dopolnilnega oz. dodatnega pouka ter obiskovanja individualne oz. skupinske pomoči. Če učenec kljub vsem učiteljevim prilagoditvam pri rednem in dopolnilnem pouku ter $\mathrm{v}$ okviru podaljšanega bivanja ne napreduje, potem se na učiteljevo pobudo ali pobudo staršev vključi še svetovalni delavec. Naslednja stopnja pomoči pa je pomoč $\mathrm{v}$ obliki individualne oz. skupinske pomoči.

\section{Prilagoditve preverjanja, ocenjevanja, napredovanja in opravljanja NPZ za priseljenske učence}

Od leta 2008 imajo priseljenski učenci možnost do dvoletnega prilagojenega preverjanja in ocenjevanja znanja ter možnost napredovanja $\mathrm{v}$ naslednji razred kljub neocenjenosti. Priseljenski učenci v prvem letu vključitve $\mathrm{v}$ osnovno šolo nacionalno preverjanje znanja opravljajo prostovoljno. Odgovornost za prilagojeno preverjanje in ocenjevanje znanja prenaša zakonodaja na celoten učiteljski zbor, in to $\mathrm{v}$ dogovoru s starši. Pravne podlage za izvajanje prilagojenega ocenjevanja so zelo splošne in ohlapne, vsaka šola pa se po svoje spopada $\mathrm{z}$ ocenjevanjem priseljenskih učencev. Prilagoditve se izvajajo na posameznih šolah različno (Vižintin, 2013): 
- $\quad$ učenci priseljenci prvo leto po vpisu niso ocenjeni ali pa so ocenjeni le pri posameznih učnih predmetih in kljub temu napredujejo v višji razred;

- učitelji preverjajo in ocenjujejo znanje na različne načine: ustno, individualno, s podaljšanim časom pisanja, $\mathrm{z}$ dodatno razlago, možnostjo uporabe slovarja ali spletnega prevajalnika, uporabo slikovnega gradiva;

- $\quad$ pri preverjanju in ocenjevanju priseljenski učenci uporabljajo svoj materni jezik ali skupni vmesni jezik, ki ga razume tako učenec priseljenec kot učitelj;

- $\quad$ učitelji pripravljajo za priseljenske učence posebne učne liste, $s$ pomočjo katerih dosegajo standarde znanja skladno $\mathrm{z}$ individualnim napredkom posameznega učenca priseljenca (ki se spremlja v individualnem programu).

Ohlapnost pravil je lahko priložnost za fleksibilno prilagajanje individualnim situacijam. Učitelji lahko tako po svoji presoji nekatere standarde znanja ocenijo v tekočem šolskem letu, nekatere pa šele v naslednjem.

\section{Individualni program}

Pomoč otrokom, ki imajo učne težave, in v to skupino so vključeni tudi priseljenski učenci ali »drugojezični oz. socialno-kulturno drugačni učenci«, je lahko nudena tudi s pomočjo koncepta individualnega programa (Magajna idr., 2008, str. 68).

Smernice (2007) predlagajo, naj šola glede na ugotovljeno predznanje priseljenskega učenca izdela individualni načrt aktivnosti, ki vsebuje načrt notranje individualizacije in diferenciacije, program dopolnilnega in dodatnega pouka ter druge ukrepe, tako da upošteva učne in druge potrebe ter specifiko učencev, ki pripadajo drugim kulturam. Individualni načrt aktivnosti pa naj vključuje tudi načrt spremljanja doseganja vzgojno-izobraževalnih ciljev ter vloge in odgovornosti strokovnih delavcev, učenca in staršev. Ker prihajajo učenci priseljenci z različnimi predznanji, se zdi smiselno, da se za vsakega učenca pripravi individualni program, ki vključuje informacije o učenčevem predhodnem šolanju, predznanju, izpostavijo se njegova močna in šibka področja, vanj učitelji posameznih predmetnih področij zapišejo cilje, prilagoditve pri učnih predmetih ter jih tudi spremljajo in evalvirajo. Načrtovane so vsebinske prilagoditve in tudi prilagoditve ocenjevanja. 
K. Skubic Ermenc (2010b) je do tega, da se z učenci priseljenci postopa po nekih posebnih postopkih in se zanje pripravljajo posebni programi, kritična. Predlaga pripravo individualnih programov za vse učence, saj bi tako individualizirali in diferencirali pouk brez stigmatizacije.

\section{Podporne oblike pomoči priseljenskim učencem v šolski praksi}

V zadnjem desetletju so se v Sloveniji izvajali številni projekti, dejavnosti, raziskave in usposabljanja za spodbujanje medkulturnosti, učenje slovenščine kot drugega jezika, aktivnega državljanstva, medkulturnega dialoga, razvoj medkulturne zmožnosti vseh prebivalcev, saj so praksa in raziskave pokazale, da za uspešno vključitev priseljenskega učenca ni dovolj le njegova vključitev v razred sovrstnikov, ampak da so za uspešno vključevanje priseljenskih učencev odgovorne tako šole $\mathrm{z}$ učitelji kot širše družbeno okolje. Nekatere slovenske osnovne šole so v sodelovanju z zunanjimi institucijami v okviru projektov že oblikovale podporne mehanizme za lažje vključevanje učencev priseljencev v šolo, ki lahko predstavljajo dobro izhodišče za uspešno vključevanje priseljenskih učencev v osnovne šole (Vižintin, 2013; Knez, 2012). Cilj teh programov je omilitev »kulturnega šoka« in ublažitev njihovih socialnih stisk (osamljenost, odrinjenost, zaznamovanost), ki jih doživijo priseljenski učenci ob selitvi v novo okolje in vstopu v šolo. Nekatere podporne oblike pomoči so predstavljene v nadaljevanju.

\section{Intenzivni tečaj slovenščine pred vključitvijo v pouk}

$\mathrm{Na}$ Centru za slovenščino kot drugi/tuji jezik so izvedli pet pilotnih tečajev slovenščine, $v$ katere so se vključili učenci priseljenci ob začetku njihovega šolanja v Sloveniji in njihovi starši. V tečaj so vključili tudi učence, ki so slovenske šole obiskovali že preteklo leto, vendar $\mathrm{v}$ znanju slovenščine niso napredovali. Tečaji so bili zelo intenzivni (pouk je potekal štirinajst dni vsak dan po šest šolskih ur, skupaj torej 60 ur) in so, kot so poročale šole, bistveno pripomogli $\mathrm{k}$ uspešni vključitvi učencev v pouk in druge šolske dejavnosti. Potekali so na izbranih šolah. Tečaji, ki so vključevali spoznavanje osnovnega besedišča in sporazumevalnih vzorcev, urjenje v vseh štirih jezikovnih spretnostih ter seznanjanje s sociokulturnimi vsebinami, so se izkazali za dobro rešitev pri začetnem učenju slovenščine. Šole so po končanih projektih želele nadaljevati s tako obliko začetnega poučevanja 
slovenščine, vendar zaradi finančnih omejitev takih tečajev po koncu projekta ni bilo več možno izpeljati (Knez, 2012).

Strnjeni uvodni tečaji so že prepoznani kot smiselno učenje novega jezika, za katerega izkušnje kažejo, da povečuje možnosti za uspeh, hitrejšo vključitev in napredovanje (Knez, 2012; Skubic Ermenc, 2010a; Bela knjiga, 2011). Vendar pa so v tem primeru priseljenski učenci izolirani od drugih učencev. Raziskave kažejo, da se v pripravljalnem razredu priseljenski učenci sicer naučijo osnovnega jezikovnega znanja, da pa mora biti segregacija kratka, sicer so učinki negativni (učenci ostajajo predolgo v teh razredih). Hkrati raziskave kažejo, da mora biti jezikovni tečaj povezan $\mathrm{z}$ učnim načrtom. Tudi K. Skubic Ermenc (2010a) opozarja pred segregacijo, saj je prav raziskava PISA pokazala, da so višji učni dosežki verjetnejši v enotnih kot pa $\mathrm{v}$ diferenciranih izobraževalnih sistemih, to pa pomeni, da diferencirani sistem razlike povečuje. Tako morajo biti cilj rešitev čim manj togega in tem bolj kratkotrajnega ločevanja učencev. Najmanj pa so učinki ločevanja škodljivi takrat, ko se prilagajanje pouka dogaja znotraj večinskega oddelka, torej pri notranji diferenciaciji in individualizaciji (Skubic Ermenc, 2010a, 271). Tudi Medveš (2006) na podlagi raziskav OECD in PISA zagovarja notranjo diferenciacijo, ki upošteva potrebo vsakega posameznika, torej zagovarja individualizacijo pouka.

V Beli knjigi (2011) se je stroka izognila segregaciji priseljenskih učencev in je kot rešitev predlagala strnjeni program slovenščine, $v$ katerem bi se učenci v določenem deležu udeleževali tudi rednega pouka skupaj s sošolci. Za program bi se oblikoval posebni učni načrt za slovenščino kot drugi/ tuji jezik. Tudi učitelji vidijo pozitivno stran intenzivnih tečajev slovenščine in jih podpirajo. Raziskava (Krek in Vogrinc, 2011) je pokazala, da večina osnovnošolskih učiteljev ( $88 \%$ ) meni, da bi morali učenci, katerih materni jezik ni slovenščina in slovenščine ne obvladajo, pred vključitvijo v slovensko osnovno šolo začetno znanje slovenščine pridobiti na posebnem intenzivnem tečaju. Več kot polovica osnovnošolskih učiteljev $(54,6 \%)$ meni, da bi morali učenci na takšnem tečaju pridobiti tudi osnovno znanje drugih predmetov.

\section{Pripravljalnica: uvajalnica in nadaljevalnica}

V zadnjih letih se pripravljalna faza pojavlja na posameznih šolah, na katerih je odstotek priseljenskih učencev višji. Na nekaterih šolah izvajajo "pripravljalnico «, ki jo sestavljata »uvajalnica i in »nadaljevalnica«. Uvajalnica se začne izvajati pred začetkom šolskega leta $\mathrm{v}$ zadnjem tednu avgusta. 
Namenjena je pomoči novopriseljenim učencem pri kulturnem in jezikovnem vključevanju v novo okolje. Novopriseljeni učenci se naučijo osnovnih sporazumevalnih vzorcev v slovenščini, spoznajo se s kulturno dediščino države gostiteljice ter vsebinami državljanske in domovinske vzgoje. Poleg tega lahko drugim predstavijo tudi svoj jezik in kulturo, se spoznajo $\mathrm{z}$ učitelji, učitelji pa se srečajo s starši (Jelen Madruša, 2010a; 2010b). Tako se poveča verjetnost, da se bo sodelovanje s starši ohranilo skozi vse leto. $\mathrm{V}$ nadaljevanju se spoznajo $\mathrm{z}$ učnimi in dnevnimi vsebinami, ki bodo del njihovega življenja v novem okolju (šola in življenje v šoli, potrebščine, predmeti in drugo). Tako se predpostavlja, da učenci v šolo pridejo manj prestrašeni, se počutijo varnejše in bolj sprejete, še pred začetkom šolanja pa se seznanijo tudi z novim jezikom (Jelen Madruša, 2010a; 2010b).

\section{Vrstniško in medvrstniško tutorstvo ter vrstniška pomoč}

Pri uspešnem vključevanju učencev priseljencev lahko ključno vlogo odigrajo tudi sovrstniki. Vrstniška pomoč, uporablja se tudi termin vrstniško tutorstvo, predstavlja obliko pomoči vrstnika vrstniku na različnih področjih (Dubois in Karcher, v Jereb, 2011). V Sloveniji kot vrstniško tutorstvo štejemo različne oblike sodelovalnega učenja $\mathrm{v}$ paru (pri tem medvrstniško tutorstvo pomeni tutorstvo med različno starima učencema, vrstniško tutorstvo pa med enako starima učencema), kot vrstniško pomoč pa različne oblike učenja v skupini enako starih učencev (Jereb, 2011, str. 95). Pri tutorstvu med različno starimi učenci tutor predstavlja model vzornega obnašanja, organiziranja dela, postavljanja vprašanj, predstavlja lastno učinkovito učenje in spodbuja izboljšanje učnih navad učenca, s katerim sodeluje (Gaustad; Miller in Miller, v Jereb, 2011). Na področju vključevanja učencev priseljencev je medvrstniško tutorstvo namenjeno učencem priseljencem kot dodatna pomoč pri razumevanju in usvajanju učne snovi posameznih predmetov pa tudi učenju slovenščine prek skupnega maternega jezika. Hkrati pa se, kot navajata Bešter in Medvešek (2010, str. 231), v določenih pogledih otrok lažje in hitreje identificira $\mathrm{z}$ vrstnikom kot $\mathrm{z}$ učiteljem in lahko zaradi tega bolje napreduje ob pomoči vrstnika. Medvrstniško druženje ne omogoča samo pomoči pri usvajanju učne snovi, ampak tudi lažje in hitrejše učenje nenapisanih pravil in norm obnašanja.

\section{Druge podporne oblike pomoči priseljenskim učencem $v$ Sloveniji}

Tudi nevladne in prostovoljske organizacije (npr. Slovenska filantropija, Mirovni inštitut, Inštitut za afriške študije ter številne druge ustanove, 
zavodi in društva) lahko še kako vplivajo na vsa področja življenja priseljenskih učencev in njihovih staršev. A. Mikuš Kos (1996, str. 36-37) meni, da lahko nevladne organizacije vplivajo na: (1) življenje in zdravje neposrednih porabnikov (npr. na otroke s psihosocialnimi motnjami, ki jim pomagajo prostovoljci, ali vplivajo na starše), (2) družino osebe, ki ji pomagajo (npr. na starše otroka $\mathrm{z}$ učnimi težavami, ki mu prostovoljec pomaga), (3) prostovoljne delavce (na občutek socialne koristnosti, zadovoljstva, osebnostne rasti, povezovanje $\mathrm{z}$ ljudmi, pridobivanje novih znanj in izkušenj), (4) socialnovarstvene in zdravstvene ustanove (na izboljšanje kakovosti delovanja, ugodnejša psihosocialna klima, večja motivacija bolnikov ali varovancev za zdravljenje ali aktivnosti, zmanjševanje psihičnih obremenitev osebja in podobno), (5) širšo družbo (glede vrednot, kot so odgovornost do lastnega ravnanja, osveščenost, solidarnostno vedenje in podobno), (6) zakonodajo, (7) uveljavljanje človekovih pravic in otrokovih pravic in (8) pokrivanje potreb (poskrbijo za nekatere potrebe, za katere država ne zmore poskrbeti oz. državi olajšajo izvajanje nekaterih dejavnosti). Avtorica poudarja, da nevladne in prostovoljske organizacije postajajo vse bolj pomembna ekonomska kategorija, ki ljudem pomaga na različne načine (npr. ustvarja nove socialne mreže, servise, nova delovna mesta).

V nekaterih osnovnih šolah v Sloveniji skušajo priseljenskim otrokom lajšati vzpostavljanje vezi s slovenskim jezikom tudi tako, da jim priskrbijo zasebne ure slovenščine, ki jih omogočajo prostovoljci z različnih oddelkov Filozofske fakultete. Spet druge šole poiščejo prevajalce, ki prevajajo šolske teste v materne jezike priseljenskih učencev (Mikuš Kos, 1996, str. 36-37). $\mathrm{V}$ nekaterih šolah poleg teh dejavnosti potekajo tudi druge aktivnosti (npr. strokovna pomoč/svetovanje šolam pri vključevanju priseljencev), ki jih izvaja Zavod republike Slovenije za šolstvo.

Podporne oblike pomoči priseljenskim učencem v šolski praksi se torej uresničujejo preko intenzivnih tečajev slovenščine pred vključitvijo $\mathrm{v}$ pouk, pripravljalnic, vrstniških in medvrstniških tutorstev, vrstniške pomoči in s pomočjo nevladnih in prostovoljnih organizacij, vendar je to prej izjema kot pravilo. Vključevanje priseljenskih učencev v vzgojno-izobraževalni sistem poteka predvsem $\mathrm{v}$ obliki dodatnega pouka slovenščine, ki je v slovenski zakonodaji različno opredeljen, dejanska praksa pa z zakoni ni vedno usklajena. Priseljenskim otrokom, za katere se ugotovi, da slovenskega jezika še ne znajo oz. ga še ne obvladajo dovolj, se praviloma odobri največ 1 ura dodatnega pouka slovenščine na teden, kar pomeni največ 35 ur na leto. Obseg ur za posameznega otroka glede na okoliščine določi 
Ministrstvo za izobraževanje, znanost in šport, način izpeljave pouka pa izberejo šole same. Posebnih zakonskih določil, kdo naj izvaja tak pouk in $\mathrm{v}$ kakšni obliki, ni (Strategija, 2007, str. 4).

\section{Pomanjkljivosti obstoječe slovenske zakonodaje in drugih strokovnih dokumentov}

Slovenska osnovnošolska zakonodaja omogoča, da se $\mathrm{v}$ osnovno šolo pod enakimi pogoji lahko vključijo vsi učenci, prav tako so izražene pravice priseljenskih učencev. Zakonodaja omogoča tečaj slovenščine, pouk maternega jezika in kulture (v sodelovanju $\mathrm{z}$ izvornimi državami) ter dveletno prilagojeno preverjanje in ocenjevanje znanja. Po pregledu zakonodajnih in drugih dokumentov, ki so podlaga za delovanje vzgojno-izobraževalnega sistema in za vključevanje učencev priseljencev, lahko zaključimo, da slovenski vzgojno-izobraževalni sistem vsebuje različne elemente medkulturnega pristopa, vendar je kljub temu zaznati nekatere pomanjkljivosti v zakonodaji. K. Skubic Ermenc (2010b, str. 85-86) je kritična do ciljev vključevanja, ki so našteti v Strategiji (2007) in Smernicah (2012), ter opozarja, da so priseljenski učenci obravnavani kot posebna kategorija, ki jih definira stopnja primanjkljaja (tj. stopnja obvladovanja slovenščine) ter da se večina ciljev nanaša nanje. Le cilj, ki predvideva medkulturno kulturo šole, v kateri se še posebej skrbi za dosežke priseljenskih učencev, se nanaša na celotno šolsko populacijo. K. Skubic Ermenc (2010b) opozori, da bi cilje lažje realizirali, če bi bilo osnovno izhodišče Strategije (2007) razvoj medkulturno zasnovane vzgoje in izobraževanja in ne vključevanje priseljenskih učencev. Priseljenski učenci imajo po vključitvi v redne oddelke osnovne šole le nekaj oblik podpore. Vendar pa slovenski avtorji in raziskovalci vzgoje in izobraževanja opozarjajo tako na pomanjkljivo zakonodajo kot neustrezno šolsko prakso (Lesar, 2009; Bešter in Medvešek, 2010; Mikulec, 2010; Lesar idr., 2012; Vezovnik, 2013), saj je velikokrat uspešno vključevanje priseljenskih učencev odvisno tudi od podpore in prizadevanja posameznega ravnatelja in/ali učitelja (Bela knjiga, 2011).

M. Vižintin (2010) in Bela knjiga (2011) opozarjata, da se priseljenski učenci ne učijo slovenščine kot drugega jezika, da je število ur za učenje slovenščine preskromno, za poučevanje slovenščine kot drugega jezika ni niti učnega načrta. Učenec priseljenec, ki ne obvlada jezika okolja, torej slovenščine, ima najverjetneje težave tudi pri drugih predmetih, hkrati pa tudi težave pri vključevanju $\mathrm{v}$ družbo. Tudi na področju učenja maternega jezika in kulture osnovne šole ne zagotavljajo uresničevanje pravic učencem, da 
se učijo svojega maternega jezika, saj le redke šole ponujajo učenje maternega jezika kot dopolnilno učenje, nekaj šol pa v sklopu izbirnega predmeta v tretjem triletju, pa še to gre za učenje tujega jezika. Učni načrti sicer predvidevajo medkulturne vsebine in učiteljem omogočajo, da jih lahko vpletejo v svoj predmet. O spoznavanju kultur priseljenskih učencev v slovenskih šolah I. Lesar (2009, str. 340) razlaga, da se skozi vidik prisotnosti drugih kultur v učnih načrtih obveznih predmetov postavlja resen dvom o možnosti spoznavanja in razvijanja oz. življenja lastne kulture teh učencev, saj je v kurikulih prepoznavna monokulturna naravnanost, ki se na ravni poučevanja izraža s proučevanjem kulturno drugačnih, ki so ekonomsko in socialno na slabšem. Vezovnik (2013) celo trdi, da se vključevanje, ki se navzven kaže kot demokratični poskus vključitve otrok, katerih prvi jezik ni slovenščina, v slovenske šole, v praksi izkaže za klasično asimilacijsko strategijo. Integracijska politika s svojimi ukrepi utrjuje dana razmerja moči v družbi in družbeni nadzor države in družbene večine nad manjšinskimi populacijami ter nastopa predvsem kot etnocentrična ideologija. K. Skubic Ermenc (2007) pa opozarja na zaskrbljujočo diskrepanco med tistim, za kar se javno zavzemamo, in med tistim, kar zares delamo in v sebi menimo. Splošna ugotovitev za slovensko šolo je, da kljub zavzemanju za integracijo in inkluzijo na ravni šolskega sistema (skladno z drugimi družbenimi sistemi) še vedno delujemo asimilacijsko. Želimo torej, da se vsi državljani in prebivalci Slovenije nasploh prilagodijo nam, da postanejo Slovenci (Skubic Ermenc, 2007, str. 134).

Pomanjkljivost obstoječega sistema se kaže tudi v tem, da Ministrstvo za izobraževanje, znanost in šport ne vodi evidence vpisanih priseljenskih učencev v osnovne šole. Na podlagi vlog šol za soglasje $\mathrm{k}$ uram dodatne strokovne pomoči (učenje slovenščine) za priseljenske učence, ki se prvo leto šolajo v Sloveniji, lahko Ministrstvo za izobraževanje, znanost in šport posredno in okvirno ugotovi le, koliko teh učencev se je všolalo v tekočem šolskem letu (Magdič in Straus, osebna komunikacija, januar in februar 2010; v Sinjur, 2010). Vrtci in šole ob vpisu priseljenskih učencev prav tako ne zapisujejo maternega (prvega) jezika otrok. Po podatkih, ki jih navaja Klinar (2010) je v osnovne šole v Sloveniji vključenih 5,2 \% otrok, katerih materni jezik ni slovenščina. Knaflič (2010) meni, da smo si s tako strogim režimom varovanja osebnih podatkov otežili preverjanje nepravičnosti sistema do jezikovnih manjšin. 


\section{Predlagani ukrepi in možne rešitve pri vključevanju priseljenskih učencev v vzgojno-izobraževalnih institucijah}

Učinkovitejše in pravičnejše vključevanje priseljenskih učencev v slovenski vzgojno-izobraževalni sistem je v veliki meri odvisno od znanja slovenščine. Bela knjiga (2011) predlaga tako obliko učenja slovenščine, ki jih bo motivirala ter omogočila hitro in učinkovito jezikovno napredovanje, hkrati pa učencev ne bo izključevala. Predlagajo bistveno povečano število skupnih ur in obvezno strnjeno obliko jezikovnega tečaja. Šola naj samostojno ali v sodelovanju $\mathrm{z}$ drugimi šolami na določenem območju oblikuje skupine za učenje maternega jezika in kulture za učence, katerih materni jezik ni slovenščina. Drugi materni jezik priseljenskih učencev bi se moral poučevati tako, da ga šole ponudijo kot izbirni predmet po posebnem kurikulu. Različni avtorji se strinjajo, da bi se sistematično učenje jezika okolja za priseljenske učence moralo začeti že pred vstopom v osnovno šolo. Tako bi učenci svoje znanje in razumevanje slovenskega jezika lahko začeli utrjevati že pred vstopom $\mathrm{v}$ formalno izobraževanje in bi se njihovi učni rezultati lahko izboljšali. S tem se strinja tudi B. Hanuš (2010), ki pravi, da bi morali učencem, ki so tukaj prvo leto, posvetiti več pozornosti, saj ob vključitvi v slovensko osnovno šolo potrebujejo več pomoči, ki jim je učitelji pri pouku ne morejo ponuditi. Vsi učenci bi morali biti že pred prvim šolskim dnem deležni pouka slovenščine. Predlaga tudi pripravo programov, ki bi poleg poučevanja jezika omogočali tudi spoznavanje slovenske kulture in kultur priseljenskih učencev. Strokovno izpopolnjevanje in dopolnilno izobraževanje so zanesljivi načini, kako se lahko izobraževalne ustanove učinkovito odzovejo na večkulturnost okolja in iščejo načine za navezovanje odnosov med posamezniki različnih kultur. Poleg samega učnega procesa, ki se odziva na njihove želje in potrebe, je nujno učencem priseljencem zagotoviti tudi udobnost v okolju, kjer se nahajajo. V Smernicah (2012) najdemo kar nekaj predlogov zagotavljanja medkulturnega okolja: zemljevidi sveta $\mathrm{z}$ označenimi državami izvora otrok priseljencev, pozdravi v jezikih otrok na hodnikih, prirejene brošure, spletne strani z vsaj osnovnimi informacijami $\mathrm{v}$ drugih jezikih, slikovne in besedne oznake otrok v šoli. Na področju sodelovanja s starši pa predlagajo pomoč pri izpolnjevanju vpisnih dokumentov, seznanitev staršev s pravicami in dolžnostmi, vključitev staršev v življenje in delo šole, ponuditi možnost učenja slovenskega jezika za učence in starše priseljence. Šola pomaga in sodeluje pri prevajanju, pripravi brošure za starše, spodbuja družinsko branje knjig, v knjižnici organizira tematska srečanja otrok in staršev. Tatković (2001) predlaga tudi vpeljavo nekaterih 
tem v učni proces, in sicer vzgoja za sprejemanje različnosti v jeziku, veri, stališčih, vedenju; spoznavanje drugih kultur in njihovih sestavin (gostovanja, izmenjave, ekskurzije); premagovanje predsodkov in socialnih stereotipov o posameznikih, ki pripadajo drugi kulturi; učenje jezika drugih kultur; uporaba nove tehnologije in medijev, s katerimi lahko znanje hitreje širimo. Kot smo izpostavili že zgoraj, je vzgoja v večkulturnih razredih uspešna le, če bodo v načrtovanje kurikuluma vključeni tudi starši. Starši so zadovoljni, če so vključeni v proces učenja svojih otrok, in lažje pomagajo svojim otrokom, ker jih bolje poznajo; na splošno imajo starši pri učenju drugega jezika zelo pomembno vlogo, saj lahko s svojim ravnanjem pozitivno vplivajo na otroka in prispevajo $\mathrm{k}$ njegovem uspehu s pohvalami in spodbudami (Knaflič, 1991).

Pri vključevanju priseljenskih učencev v slovenski vzgojno-izobraževalni sistem bi bila torej nujno potrebna aktivna podpora države, s konkretnimi ukrepi in sistemskimi rešitvami ter spodbudami, s katerimi bi pomagali pri vključevanju, saj lahko samo več sočasnih strokovno utemeljenih sprememb in ukrepov prinese rezultate.

\section{Literatura}

Bela knjiga o vzgoji in izobraževanju v Republiki Sloveniji. (2011). Krek, J. in Metljak, M. (ur.). Ljubljana: Zavod Republike Slovenije za šolstvo.

Berdajs, A. (2016). Socialnopedagoško delo učiteljev z rizičnimi dijaki v strokovnih šolah. V IV. International Scientific conference "Special education and rehabilitation - early intervention « (str. 196). Beograd: Beogradska defektološka škola.

Bešter, R., in Medvešek, M. (2010). Vključevanje migrantskih otrok v vzgojno-izobraževalni sistem. V M. Medvešek, in R. Bešter (ur.), Državljani tretjih držav ali tretjerazredni državljani?: integracija državljanov tretjih držav v Sloveniji (str. 205-269). Ljubljana: Inštitut za narodnostna vprašanja.

Direktiva Sveta $z$ dne 25. julija 1977 o izobraževanju otrok delavcev migrantov (77/486/EGS). Pridobljeno s http://eur-lex.europa.eu/legal-content/SL/ TXT/PDF/?uri=CELEX:31977Lo486\&qid=1406829546826\&from=EN

Hanuš, B. (2010). Jezikovne in kulturne ovire, ki vplivajo na opismenjevanje učencev priseljencev. Sodobna pedagogika, 61(1), 122-135.

Jereb, A. (2011). Strategije vrstniške pomoči za učence $\mathrm{z}$ učnimi težavami. V S. Pulec Lah in M. Velikonja (ur.), Učenci z učnimi težavami-izbrane teme (str. 94-110). Ljubljana: Pedagoška fakulteta. 
Jelen Madruša, M. (2010a). Iskanje poti pri delu z učenci migranti. V A. Baloh (ur.), Uvajanje rešitev s področja vključevanja migrantov v izvedbene kurikule (str. 7-19). Koper: Osnovna šola Koper/Scuola elementare Capodistria.

Jelen Madruša, M. (2010b). Novosti pri vključevanju učencev migrantov. V A. Baloh (ur.), Uvajanje rešitev s področja vključevanja migrantov $v$ izvedbene kurikule (str. 69-81). Koper: Osnovna šola Koper/Scuola elementare Capodistria.

Klinar, P. (2010). Medkulturno komuniciranje v šolskem prostoru. Socialna pedagogika, 14(2), 213-230.

Knaflič, L. (1991). Neslovenski otroci in šola. Jezikovni problemi otrok, ki se ne šolajo v maternem jeziku. Vzgoja in izobraževanje, 14(2), 38-41.

Knaflič, L. (2010). Pismenost in dvojezičnost. Sodobna pedagogika, 61(2), 280-294.

Knez, M. (2009). Jezikovno vključevanje (in izključevanje) otrok priseljencev. V M. Stabej (ur.), Infrastruktura slovenščine in slovenistike (str. 197-202). Ljubljana: Filozofska fakulteta.

Knez, M. (2012). Za koliko slovenščine je prostora v naši šoli? Jezik in slovstvo, $57(3-4), 47-62$.

Komac, M., Medvešek, M., in Roter, P. (2007). Pa mi vi povejte, kaj sem???! Študija o etnični raznolikosti v Mestni občini Ljubljana. Ljubljana: Fakulteta za družbene vede.

Konvencija o otrokovih pravicah (1989). OZN: Generalna skupščina OZN.

Krek, J., in Vogrinc, J. (2005). Znanje slovenskega jezika kot pogoj šolskega uspeha učencev iz jezikovno in kulturno različnih ter socialno depriviligiranih družin - primer začetnega opismenjevanja romskih otrok. Sodobna pedagogika, 56(2), 118-139.

Krek, J., in Vogrinc, J. (2011). Izbrani predlogi sistemskih rešitev v šolskem sistemu vidika socialne kohezivnosti. V B. Borota, M. Cotič, D. Hozjan in L. Zenja (ur.), Social cohesion in education (str. 79-93). Horlivka: Horlivka State Pedagogical Institute for Foreign Languages.

Lesar, I. (2009). Ali formalne rešitve na področju šolanja marginaliziranih omogočajo uresničevanje ideje inkluzije? Sodobna pedagogika, 6o(1), 334-348.

Lesar, I., Čančar, I., in Jug Došler, A. (2012). Učitelji iz Slovenije in Švedske o poučevanju (novo)priseljenih učencev. Dve domovini/Two Homelands, 36 , $59-72$. 
Magajna, L., Kavkler, M., Čačinovič Vogrinčič, G., Pečjak, S., in Bregar Golobič, K. (2008). Učne težave v osnovni šoli: koncept dela. Ljubljana: Zavod Republike Slovenije za šolstvo.

Medveš, Z. (2006). Upoštevanje drugačnosti - korak k šoli enakih možnosti. Sodobna pedagogika, 57(posebna izdaja), 10-41.

Mikuš Kos, A. (1996). Nevladne organizacije, prostovoljno delo in promocija zdravja. V E. Kraševec Ravnik (ur.), Varovanje zdravja posebnih družbenih skupin v Sloveniji (str. 25-41). Ljubljana: Inštitut za varovanje zdravja Republike Slovenije: Slovenska fondacija.

Pravilnik o preverjanju in ocenjevanju znanja ter napredovanju učencev $v$ osnovni šoli (2013). Uradni list RS, št. 52/2013. Pridobljeno 16. 10. 2013 s http:// www.uradni-list.si/1/objava.jsp? urlurid $=20131988$

Resolucija o nacionalnem programu za jezikovno politiko 2014-2018. Pridobljeno 16. 10. 2013, s http://pisrs.si/Pis.web/pregledPredpisa?id=RESO91

Sinjur, A. (2010). Učenci z imigrantskim ozadjem - politike in praksa učenja maternega jezika učencev imigrantov v nekaterih državah EU. Educa, 19(3-4), 59-69.

Skubic Ermenc, K. (2007). Interkulturnost v učnih načrtih slovenske osnovne šole. Pedagoška obzorja, 22(1-2), 128-135.

Skubic Ermenc, K. (2010a). Slovenska strategija vključevanja učencev migrantov v izobraževanje $\mathrm{v}$ kontekstu evropske izobraževalne politike. V N. Ličen (ur.), Kulture v dialogu (str. 79-89). Maribor: Grafiti Studio.

Skubic Ermenc, K. (2010b). Med posebnimi pravicami in načelom medkulturnosti. Sodobna pedagogika, 61(2), 268-279.

Strategija vključevanja otrok, učencev in dijakov migrantov $v$ sistem vzgoje in izobraževanja v Republiki Sloveniji (2007). Pridobljeno s http://www. mizks.gov.si/fileadmin/mizks.gov.si/pageuploads/podrocje/os/devetletka/ program_drugo/Smernice_izobr_otrok_tujcev_v_vrtcih

Tatković, N. (2001). Vzgoja za medkulturnost: usposabljanje za življenje v multikulturni družbi. Andragoška spoznanja, 7(2), 24-30.

UstavaSocialističnefederativnerepublikeJugoslavije.(1974).Odnosivfederacijiter pravice in dolžnosti federacije. Pridobljeno s http://sl.wikisource.org/wiki/ Ustava_Socialisti\%C4\%8Dne_federativne_republike_Jugoslavije_(1974)/ Odnosi_v_federaciji_ter_pravice_in_dol\%C5\%BEnosti_federacije

Vezovnik, A. (2013). Children whose first language is not Slovenian in the Slovenian educational system: A critical analysis of normalisation. Annales, Series historia et sociologia, 23(2), 303-316. 
Vižintin, M. A. (2010). Pouk maternega jezika in kulture pri učencih priseljencih. Sodobna pedagogika, 61(1), 104-120.

Vižintin, M. A. (2013). Vključevanje otrok priseljencev prve generacije in medkulturni dialog v slovenski osnovni šoli (Doktorska disertacija). Univerza v Ljubljani, Pedagoška fakulteta, Ljubljana.

Vižintin, M. A. (2014). Model medkulturne vzgoje in izobraževanja. Dve domovini/Two Homelands, 40, 71-89.

Zakon o organizaciji in financiranju vzgoje in izobraževanja (ZOFVI-UPB5) (2007). Uradni list RS, št. 16/2007. Pridobljeno s http://www.uradni-list.si/1/ objava.jsp? urlid=200716\&stevilka $=718$

Zakon o osnovni šoli (ZOsn) (1996). Uradni list RS, 12/1996. Pridobljeno s http:// www.pisrs.si/Pis.web/pregledPredpisa?id=ZAKO448

Zakon o spremembah in dopolnitvah Zakona o osnovni šoli (ZOsn-F) (2007). Uradni list RS, št. 102/2007. Pridobljeno s http://www.uradni-list.si/1/objava. jsp?urlid=2007102\&stevilka $=5073$ 